\title{
Salivary proteome profile of women during fertile phase of menstrual cycle as characterized by mass spectrometry
}

\section{Ganesan Saibaba}

Bharathidasan University

\section{Durairaj Rajesh}

Bharathidasan University

\section{Subramanian Muthukumar}

Bharathidasan University

\section{Ganesan Sathiyanarayanan}

Institut de biosciences et biotechnologies d'Aix-Marseille

Archunan Priya Aarthy

Rabindra Nath Tagore Medical College

\section{Parasuraman Padmanabhan}

Lee Kong Chian School of Medicine

\section{Balazs Gulyas}

Lee Kong Chian School of Medicine

\section{Mohammad Abdulkader Akbarsha}

Bharathidasan University

Govindaraju Archunan ( $\nabla$ garchu56@yahoo.co.in )

Bharathidasan University https://orcid.org/0000-0002-7094-0351

\section{Research article}

Keywords: Saliva, Ovulation, Biomarker, Cystatin, Gel electrophoresis, Protein, LC-MS/MS, SDS-PAGE

Posted Date: December 19th, 2019

DOI: https://doi.org/10.21203/rs.2.13524/v2

License: (1) (i) This work is licensed under a Creative Commons Attribution 4.0 International License. Read Full License 


\section{Abstract}

Background: Human saliva contains several biomolecules, especially proteins, some of which have been found to serve as biomarkers of different physiological statuses and/or pathological conditions. Saliva is a much superior biological material for investigation over the other body fluids. Ovulation is such a critical physiological process that its non-invasive detection based on salivary protein biomarkers has several advantages in the human. Therefore, it was hypothesized that saliva would potentially contain non-invasive predictor(s)/detector(s) of ovulation. Methods: Samples were collected from women volunteers. The procedure adopted was approved by the Institutional Ethical Committee (DM/2014/101/38), Bharathidasan University. The saliva samples were collected between 8.00 to 9.00 AM from 30 healthy female volunteers (age, mean $=24$, range $=19-30$ ), with a prior written consent. The protein expression pattern during different phases of menstrual cycle was analyzed using gel-based HRLC-MS/MS and MALDI TOF/TOF. Results: As many as 530 proteins showed up in the saliva during ovulation phase whereas there were only 251 proteins during post-ovulation phase. The functional annotation of salivary proteins revealed that the proteins got assigned to the class of "extracellular proteins" which are concerned with regulatory functions. The 16 unique/differentially expressed protein spots appeared during ovulation phase, among which Cystatin-S, Prolactin-inducible protein, Cystatin-A, Cystatin-SN, BPI fold-containing family A member 2, Alpha-tubulin N-acetyltransferase 1, Carbonic anhydrase-6, Protein LEG1 homolog, Hemoglobin subunit beta, Pancreatic alpha-amylase were identified. Conclusions: These ten proteins that were highly expressed during ovulation phase would serve as indicator(s) of ovulation, but extensive validation is required before arriving at a conclusion.

\section{Introduction}

Saliva is a clear oral fluid composed of $98 \%$ water and $2 \%$ other compounds such as mixture of proteins, electrolytes and small molecular weight organic compounds. The term saliva stands for secretions from the major (submandibular, sublingual and parotid) and minor salivary glands. Normally, human salivary glands secrete about 1.0-1.5 L saliva every day, which contains molecules from blood and salivary protein combined [1]. The secretion of saliva is regulated by the autonomic nervous system via signal transduction systems that couple receptor stimulation to ion transport and protein secretory mechanisms [2]. In recent years, saliva has been recognized as a diagnostic tool and general health indicator. Many salivary biomolecules arrive from the blood through passive intracellular diffusion and active transport or extracellular ultrafiltration [3]. The levels of salivary components vary in respect of the spectrum of oral and general health. For example, low levels of lysozymes [4] and presence of lactoferrin [5] were observed in saliva under a condition of dental caries. In the beginning of menstruation and during ovulation the protein content of saliva increases considerably, which turns out to be a rich source of nutrient to bacteria the count of which may increase during menstruation and ovulation [6]. The concentration of analytes in saliva is 100 - to 1000 -fold lower compared to blood [7]. As diagnostic fluid saliva and urine offer many advantages over blood, which include (i) simple, cost-effective and non-invasive nature of sample 
collection, (ii) no need of skilled personal to collect saliva, and (iii) the protein concentration of saliva is lesser than plasma. The third attribute renders saliva easier to investigate for diagnostic purposes [7].

Most of the animals have limited and short fertile period (estrus) and the external indications and attractiveness synchronize with ovulation and maximize the chance for fertilization [8, 9]. In human, females do not show corresponding cyclical changes that would be an indicator of ovulation, therefore, it was felt essential to develop a method to identify the time of ovulation during the reproductive cycle [10]. The time of ovulation in human is associated with the fertile phase of menstrual cycle. In the mammals, it is generally accepted that many reproductive processes such as ovulation, menstruation, implantation and parturition are linked with inflammation [11]. As the consequence of these processes there is upregulation of a host of inflammatory mediators, which include cytokines, growth factors and lipid mediators which influence the growth and function of the immune and vascular compartments [12]. Similarly, in response to inflammation in an ovary, there are specific pro- or anti-inflammatory cytokine/protein expressions in the body fluids. This can as well be utilized to predict the time of ovulation [13]. Still there is not yet a reliable non-invasive modality to detect the time of ovulation. Hence, a method for accurate prediction or detection of the fertile phase during menstrual cycle has enormous significance in promoting or controlling fertility. Saliva, for the reasons mentioned above, has long been speculated to possess one or more biomarkers indicting important events in the reproductive cycle. Thus, we adopted a proteome-based approach to detect salivary biomarkers for fertile phase [13]. The complex protein mixtures were analyzed qualitatively by SDS-PAGE [14], which suggested that SDSPAGE is an adequate technique to assess the protein composition of the human saliva [15]. However, in the recent times, 2-D SDS-PAGE is used to separate complex protein mixtures of saliva based on the different modifications and isoforms of the same protein and recent advancements in mass spectrometry techniques are adopted to better facilitate protein biomarker identification in saliva [3]. In our previous study [16], the ovulation-specific proteins in saliva were mapped, and validated. Hence, it was thought that the identification of an ovulation-specific protein in saliva would do well for future application. Therefore, the present study was directed towards identifying the proteins in human saliva in relation to phases in the menstrual cycle by adopting 1D and 2D gel electrophoresis followed by mass spectrometry (Figure S1) to discern the various proteins, and map the ovulation-specific proteins.

\section{Materials And Methods}

\section{Volunteers' information and ethical statement}

Samples were collected from women volunteers, and the procedure adopted was approved by the Institutional Ethical Committee (DM/2014/101/38), Bharathidasan University. The saliva samples were collected between 8.00 to 9.00 AM from 30 healthy female volunteers (age, mean $=24$, range $=19-30$ ), with a prior written consent [16]. The volunteers were instructed not to consume food and/or soft drink for $10 \mathrm{~h}$ before the sample collection. The volunteers were also asked to brush the teeth $30 \mathrm{~min}$ before collection of saliva so as to prevent microbial contamination. 


\section{Sample collection and process}

The saliva was collected by spitting method. The duration of collection of saliva was about 10 min and the saliva secretion over the first minute was discarded. The collected samples were kept in an ice box and brought to the laboratory without any time delay. The samples were centrifuged at $16000 \mathrm{xg}$ for 15 min to remove insoluble materials and cells, if any. The samples were stored at $-80^{\circ} \mathrm{C}$ until further use. The saliva samples were assigned among three phases, viz., pre-ovulatory (day 6 to 12), ovulatory (day 13 and 14) and post-ovulatory (day 15 to 26), according to the pattern of salivary hormones and fern pattern analysis, as was done in our previous study[16].

\section{Protein precipitation and estimation}

The salivary proteins were precipitated by trichloroacetic acid (TCA)-acetone precipitation method [17]. The samples were mixed with TCA:acetone (TCA-20\% W/V; Acetone-90\% V/V) in 1:1 ratio and $20 \mathrm{mM}$ dithiothreitol (DTT) and incubated overnight at $-20^{\circ} \mathrm{C}$. After incubation, the samples were centrifuged at $5000 \times \mathrm{g}$ at $4^{\circ} \mathrm{C}$ for $30 \mathrm{~min}$. The pellets were washed twice with cold acetone and centrifuged at $5000 \times \mathrm{g}$ at $4{ }^{\circ} \mathrm{C}$ for $30 \mathrm{~min}$. Finally, the pellets were air-dried and re-suspended in UTC (6M urea, 3M thiourea, and $8 \%$ CHAPS) buffer. The protein concentration was determined adopting the modified protocol of Bradford [18].

\section{D - Gel electrophoresis}

To resolve the salivary proteins SDS-PAGE was carried out on $12 \%$ gel and $5-15 \%$ gradient gel (Bio-Rad) by adopting the modified method of Laemmli [19]. Standard medium-range molecular weight marker (Low-Range SDS-PAGE Standards, Bio-Rad, Hercules CA) was used as reference and it consisted of phosphorylase b $(97.4 \mathrm{kDa})$, bovine serum albumin $(66.2 \mathrm{kDa})$, ovalbumin $(45 \mathrm{kDa})$, carbonic anhydrase (31 kDa), soybean trypsin inhibitor $(21.5 \mathrm{kDa})$, and lysozyme $(14.4 \mathrm{kDa})$. The salivary protein preparation from each volunteer $(30 \mu \mathrm{g})$ was thoroughly mixed with $1 \mathrm{x}$ sample buffer [50 mM Tris-Cl $(\mathrm{pH} 6.8), 2 \%$ SDS, $10 \%$ glycerol, $0.1 \%$ bromophenol blue, and $100 \mathrm{mM} \beta$-mercaptoethanol] and kept for $1 \mathrm{~min}$ at $100{ }^{\circ} \mathrm{C}$ for complete denaturation of proteins, after which the sample was loaded onto the gel. A constant current of $50 \mathrm{~V}$ was applied for electrophoresis and the entire setup was maintained at room temperature.

\section{Iso-electric focusing}

Protein samples were mixed with an equal volume of UTC buffer (6M urea, 3M thiourea, $8 \%$ CHAPS, 100 mM DTT, and 2\% IPG buffer (GE, Amersham), and incubated for 30 min in ice. The content was then 
diluted to the required volume using rehydration buffer (7M urea, 2M thiourea, 4\% CHAPS, 0.5\% ampholytes, 50 mM DTT, 1\% IPG buffer (GE, Amersham), and 0.004\%b blue. De-streak TM reagent (GE Healthcare) was used for better resolution. The strips were then focused in IPGphor III after $16 \mathrm{hr}$ of passive rehydration. The programme used for focusing $11 \mathrm{~cm}(3-10 \mathrm{pH}) \mathrm{IPG}$ strips was as follows: $200 \mathrm{~V}$ 3 hrs (Step and Hold); 500 V-2 hrs (Step and Hold); 2000 V-1 hr (Gradient); 4000 V- 2 hrs (Gradient); 6000 $\mathrm{V}-2 \mathrm{hrs}$ (Gradient); $8000 \mathrm{~V}-6 \mathrm{hrs}$ (Step and Hold). The focused strips were stored at $-80{ }^{\circ} \mathrm{C}$ until further analysis.

\section{D - Gel electrophoresis}

The frozen strips were brought to room temperature and subjected to reduction and alkylation. For reduction, the strips were incubated in SDS-equilibration buffer I (6 M urea, $50 \mathrm{mM}$ Tris-Cl, 30\% glycerol, $2 \%$ SDS, $0.004 \%$ bromophenol blue, and $1 \%$ DTT) for $15 \mathrm{~min}$ in a gel rocker. For alkylation, the strips were incubated in SDS-equilibration buffer II (6 M urea, 50 mM Tris-Cl, 30\% glycerol, 2\% SDS, 0.004\% bromophenol blue, and $2.5 \%$ iodoacetamide) for $15 \mathrm{~min}$ in a gel rocker. The strips were then placed on top of $12 \%$ polyacrylamide gel $(14 \mathrm{~cm} \times 14 \mathrm{~cm} \times 1 \mathrm{~mm})$ and sealed with an overlay of $0.5 \%$ agarose solution. In the electrophoresis apparatus, the upper tank contained $2 x$ tris-glycine buffer ( $0.6 \%$ tris, $2.88 \%$ glycine, and $0.2 \%$ SDS) and the lower tank was filled with $1 \mathrm{x}$ buffer. The electrophoresis conditions were $0.5 \mathrm{~W}$ for $45 \mathrm{~min}$ and $2 \mathrm{~W}$ for 5 to $6 \mathrm{hrs}$ until the tracking dye reached the bottom of the gel plate.

\section{Colloidal Coomassie blue staining}

After electrophoresis, the gels were rinsed with distilled water and fixed with fixative solution (10\% acetic acid, $40 \%$ ethanol, and $50 \%$ distilled water), following which gels were stained with colloidal Coomassie blue stain (0.02\% CBB G-250, 5\% ammonium sulfate, 10\% ethanol, and $2 \%$ orthophosphoric acid) solution according to Dyballa and Metzger [20].

\section{Gel analysis}

Digital images of 2D-gels were acquired using ChemiDoc ${ }^{\top M}$ XRS imaging system (Bio-Rad) with internal calibration. The acquisition parameters were $300 \mathrm{dpi}$ and epi white illumination. Gel analysis was performed by adopting PDQuest software (Bio-Rad) for spot detection, according to manufacturer's protocol. Spot volume normalization, in the various 2-DE maps, was carried out using the relative spot volumes (\% Vol). Initially, automated spot detection was performed, followed by manual editing for spot splitting and noise removal. The gels containing the largest number of protein spots for each phase were chosen as the reference gels. All other gels were matched with the reference gel by placing user 
landmarks on approximately $10 \%$ of major and minor protein spots, which were visualized to assist in automatic matching. Finally, all matches were checked for errors and edited manually.

\section{HR-LC-MS/MS}

The 1D protein spots were analyzed using 6550 i-Funnel QTOF-LC-MS/MS coupled with 1260 Infinity Nano pump and 1260 Cap pump along with 1260 Chip-cube (Agilent Technologies). The peptides were fractionated along with Solvent A $(0.1 \%$ formic acid in milliQ water) and Solvent B ( $90 \%$ acetonitrile + $0.1 \%$ formic acid $+10 \%$ milliQ water). For MS measurements, we employed the positive-ion mode with the mass range of up to $m / z 4000$ with the resolution setting 60,000 at $m / z 400$. The proteins were identified by comparison with the SWISS-PROT database entries. Search parameters for MS data were, species: Homo sapiens; Protein Mass: 0-500 kDa; Protein pl: 3-10; Enzyme: trypsin; Misscleavage: 1; Mass type: monoisotopic; Charge state: $\mathrm{MH}+$; precursor and product mass tolerance $+/-50$ and +/-100ppm, respectively; Fixed modification: carbamidomethylation of Cystine (C); and Variable modifications: oxidation of methionine $(\mathrm{M})$. The mass spectrometry proteomics data have been deposited to the ProteomeXchange Consortium (http://proteomecentral.proteomexchange.org) via the PRIDE partner repository [21] with the dataset identifier PXD004511. The ovulation (File.S1) and the postovulation protein datasets (File.S2) were obtained and listed.

\section{MALDI TOF/TOF analysis}

2D protein spot was processed using an automated gel cutter and processor (Shimadzu, Xcise ${ }^{\mathrm{TM}}$ ). The gel spots were washed and destained with $50 \% \mathrm{ACN}$ and $50 \mathrm{mM} \mathrm{NH} 4 \mathrm{HCO}$ (Solvent 1), and subjected to ingel digestion with $30 \mu \mathrm{L}$ of solvent 7 ( $50 \mu \mathrm{Lof}$ trypsin stock solution in $4 \mathrm{ml}$ of $50 \mathrm{mM}$ of $\mathrm{NH}_{4} \mathrm{HCO}_{3}$ ) for 2 hr at $37^{\circ} \mathrm{C}$. ZipTips (C18) were wetted and conditioned with $50 \%$ ACN and $0.05 \%$ TFA (Solvent 5 ) and $0.1 \%$ TFA (Solvent 3), respectively. Cleaved peptides bound to the $\mathrm{C}-18$ resin were desalted using $0.1 \%$ TFA (Solvent 3). The peptides were then eluted and spotted with $2.5 \mu \mathrm{L}$ of Solvent $4(5 \mathrm{mg} / \mathrm{mL}$ of $\mathrm{CHCA}$ in $50 \% \mathrm{ACN}$ and $5 \mathrm{mM}$ of $\mathrm{NH}_{4} \mathrm{CHO}_{3}$ ) onto a 384-well MALDI plate. Finally, samples were identified using MALDI TOF/TOF (AB Sciex 4800).

\section{Data processing}

The acquired mass spectra were processed using DataExplorer® software, and the mono-isotopic peptide masses were assigned and used in the database search. The protein identification was analysed against Homo sapiens protein sequence in MASCOT database search (http//www.matrixscience.com) using SWISS-PROT database entries. Modification of cysteine by carbamidomethylation and methionine by oxidation was allowed. The precursor and product mass tolerance were set as +/-50 and +/-100 ppm, 
respectively. Two or more unique peptides for each protein were taken for confirmation of the protein present in the sample.

\section{Functional annotation}

The salivary proteins of the ovulatory phase were further analyzed to decipher their cellular location, molecular function and biological process by STRAP 1.5 online database (http://www.bumc.bu.edu/cardiovascularproteomics/cpctools/strap/)[22].

\section{Molecular functional ontology}

The prominent salivary proteins showing up during the ovulation and post-ovulation phases were further classified based on their cellular component, biological process, and molecular function in the UniProt database (http://www.uniprot.org/). The GO entries were used to depict the percentage of proteins through Interproscan analysis in BLAST2GO. The retrieved GO ID's of protein entries, with their enrichment values, were used to generate a scatter plot by adopting Reduce Visualize Gene Ontology (REViGO) web server (http://revigo.irb.hr). The scatter plotting was carried out with semantic $\mathrm{x}$ - and $\mathrm{y}$ - axes corresponding to the log size value and $\log 10 \mathrm{P}$ value, respectively.

\section{Statistical analysis}

The protein concentration and band intensity values corresponding to ovulation, pre-ovulation and postovulation phases were represented as mean \pm SD and analysed using one-way analysis of variance (ANOVA) using SPSS 16 software (SPSS Inc., Cary, NC, USA).

\section{Results}

\section{Validation of ovulation}

It is necessary to assess the ovulation phase after appropriate screening of the menstrual cycle. Not less than 5 cycles were observed in order to confirm the length of the reproductive cycle of the volunteers prior to sample collection. Those women who exhibited normal 28 day cycle length through the 5 or more cycles were chosen to be the volunteers, and the saliva sample was collected. The ovulatory phase was confirmed from direct fertility marker viz., status of the follicle adopting ultrasonography, and biophysical fertility markers such as basal body temperature and fern pattern in saliva (Figure.S2) [23].1D - Gel electrophoresis 
The protein concentration in saliva differed slightly between ovulation and post-ovulation phases. The total proteome was fractionated by $12 \%$ SDS-PAGE (Figure 1A). The protein profile of ovulatory phase saliva was compared to that of post-ovulatory phase. Put together, during the two phases, a total of 12 distinct protein bands appeared in the Coomassie brilliant blue-stained gels, and their molecular mass ranged from 14 to $97 \mathrm{kDa}$. Further, the protein pattern was verified in the gradient gel also (Figure 1B)and it was found to be similar to that revealed in $12 \%$ SDS-PAGE. Among the various bands 66,43 , and 14.5 $\mathrm{kDa}$ were in the highest intensity during the ovulation phase compared to post-ovulatory phase.

\section{HR-LC-MS/MS analysis}

In order to identify the salivary proteins, the SDS-PAGE protein profiles of each phase were excised equally into six separate pieces, which were individually subjected to trypsin digestion followed by mass spectrometry analysis. In total, 781 proteins were identified combining ovulation and post-ovulation phases of menstrual cycle. During ovulation phase 530 proteins were found, whereas 251 proteins were found during post-ovulation phase. These results clearly indicate that the expression of more number of proteins during ovulation phase than post-ovulation phase. Among these proteins, 35 were present during both ovulation and post-ovulation phases. The schematic diagram (Venn) developed by Oliverios (http://bioinfogp.cnb.es/tools/venny), revealed the protein identities in each phase (Figure 1C).

\section{Ovulation-specific proteins}

Several functionally important ovulation phase-specific proteins were identified and listed. Table 1 shows the list of 30 functionally important proteins related to reproduction during ovulation phase. The biological functions of protein were deduced from STRAP; the theoretical pls and monoisotopic molecular weights were calculated adopting the procedure in Swiss-Prot - ExPASy website (http://web.expasy.org/compute_pi). Cystatin-S,Disintegrin,Metalloproteinase domain-containing protein 7, TANK-binding kinase 1 and Exportin 7 appeared to be predominant, having more number of peptide identifications (Table 1).

\section{Gene ontology}

The unknown, uncharacterized and repeated proteins were removed. The GO entries were predicted using GI number of proteins in UNIPROT database. After refinement of datasets it was seen that saliva of ovulation and post-ovulation phases contained 154 and $117 \mathrm{GO}$ entries, respectively. The gene ontology clearly revealed more UNIPROT entries and greater percentage of annotation during the ovulation phase than the other phases. 


\section{Functional annotation}

The salivary proteins identified during the ovulation and post-ovulation phases were subjected to functional annotation using STRAP online database. The GO terms of proteins were classified based on the biological processes in which they participate, the cellular location and the molecular function. The results revealed that the ovulation phase had a great number of GO terms and greater percentage of annotations than during the post-ovulation phase (Figure S3).

\section{Molecular functional ontology}

The GO entries were used to depict the percentage of proteins at the molecular functional level through Interproscan analysis in BLAST2GO. The cloud tag image confirmed that the proteins identified in saliva of ovulation phase are essentially those with binding property and catalytic activity. Particularly, the ovulation phase salivary proteins (Figure $2 \mathrm{~A}$ ) showed up higher number of binding proteins $(41.6 \%)$ and metal ion binding proteins (16.1\%) compared to other phases (Figure 2B). Further, the molecular functional network was constructed using GO terms of salivary proteins. The integrated network map revealed the proteins identified during ovulation phase to have glycoprotein binding, ion binding, and immunoglobulin binding properties, also with receptor activity. Additionally, molecular network analysis revealed the interaction between the identified proteins.

\section{Scatter plot for binding proteins}

Overall, molecular function analysis expounded most of the proteins thus identified to possess binding property (Figure S4). The GO terms were used to analyse the enrichment with log size by adopting REViGO to predict the scatter plot of binding proteins of each phase of menstrual cycle. Scatter plotting was carried out with semantic $X$ and $Y$ axes corresponding to log size value and log10 $p$-value, respectively. The proteins were segregated and grouped according to their functions, and displayed in different colors. The cluster of yellow bubbles during ovulation phase corresponds, to the receptor-, protein complex-, peptide-, and GABA-binding and MAP kinase activities. The GPCR-, heat shock-, hyaluronic acid-, lipid phosphatase-, and ligase-binding, and motor activity proteins are shown in linear green bubbles. GABA-A receptor activity and receptor activity proteins are denoted in orange bubbles (Figure 3A). Toll-like receptor-, fatty acid-, and lipid-binding proteins, and protein transporter activity proteins during post-ovulation phase are shown as separate clusters (Figure 3B). These proteins might be having some functional significance during ovulation phase. 


\section{D - Gel electrophoresis}

The salivary protein expression profiles were assessed during pre-ovulation, ovulation, and post-ovulation phases of menstrual cycle. In Coomassie-stained 2D gels, protein spots were present in the pl range 4-7 and the molecular weight between 14-97 kDa (Figure 4A-C). The analyses carried out during different phases using PDQuest software (Bio-Rad) showed nearly 50 spots in each phase. Particularly, there were more spots during ovulation phase, and many of them had higher densities compared to the other phases. Additionally, we found that the quantitative differences in the spots were high in 14.5 to $21 \mathrm{kDa}$ spot region of ovulatory phase proteins compared to the other phases. It was noticed that a few low molecular weight protein spots were specifically expressed during the ovulation phase (Figure 5A).

\section{Differential expression of salivary protein}

Based on the visual assessment and multi-channel image analysis from PDQuest (Bio-Rad) protein spot positions during pre- and post-ovulation phases were unchanged. Though the ovulation phase had a different protein expression compared to pre- and post-ovulation phases, 16 spots were identified as unique and highly expressed during this phase. These protein spot expressions were also validated in Melanie 3D viewer (Figure 5B).

\section{Identification of proteins from selected spots}

Sixteen spots with significant difference in intensities i.e., 2-fold increase, were excised from the 2D gel of ovulation phase salivary proteins. The spots were subjected to trypsin digestion and subjected to mass spectrometry. The monoisotopic mass were searched in the protein database of human from MASCOT search to identify the full length sequence. Spot 1 closely matched with Cystatin-S family protein with $71 \%$ sequence coverage and eight matched peptides (Figure 6A \& B, Table 2). The differentially expressed spots were identified as: Cystatin-S, Prolactin-inducible protein, Cystatin-A,Cystatin-SN, BPI foldcontaining family A member 2, Alpha-tubulin N-acetyltransferase 1, Carbonic anhydrase 6, Protein LEG1 homolog, Hemoglobin subunit beta, and Pancreatic alpha-amylase. The spots 1, 3, 4, 7, and 10 were identified as Cystatin-S and these spots might be isoforms/variants of Cystatin-S proteins (Table. 3 ).

\section{Discussion}

Saliva is an important diagnostic biological fluid, which reflects the physiological as well as biochemical changes in the body [24]. Human saliva has been subjected to proteomic analysis rather extensively adopting proteomic technique viz., two-dimensional electrophoresis followed by matrix-assisted laser desorption/ionization time-of-flight mass spectrometry (MALDI-TOF/MS) and quadrupole time-of-flight mass spectrometry (Q-TOF/MS) [25] as well as comparative proteomic analysis on intra- and inter-person variability of whole saliva using LC/ESI-TOF/MS[26]. Detailed salivary proteomic studies during 
menstrual cycle adopting the 2D-based mass spectrometry have not been conducted earlier. However, recently studies have been carried out to comprehensively catalog the salivary proteome with regard to cellular localization, biological processes and molecular functions [27]. In our previous study, we have reported that the $14.5 \mathrm{kDa}$ protein band is consistently present and we projected it as the ovulation phasespecific protein. Analysis of this band revealed that the Cystatin-S expression was significantly higher during the ovulation phase, which was further validated adopting immunoblotting, confirming that Cystatin-S is the predominant protein during ovulation [16].

In the present study, a complete proteomic catalogue on human saliva has been mapped with as much as 781 proteins during the three major phases of menstrual cycle. Among, 495 proteins are ovulationspecific, and 216 proteins are post-ovulation-specific. Many proteins reported in human saliva has been previously identified in humans under different physiological conditions. The functionally important proteins associated with reproductive mechanisms such as Cystatin-S, Disintegrin and metalloproteinase domain-containing protein 7 (ADAM7), TANK-binding kinase 1, Anoctamin-1, Carbonic anhydrase 6, and so on, appeared during ovulation phase. More specifically, Carbonic anhydrase is present during all phases of animals exhibiting estrous cycle. Indeed, there is a significant expression of Carbonic anhydrase in cattle, camel and goat [28]. In the human, recent studies have confirmed that secretion of specific peptides/proteins are different in the pediatric age compared to adults [29].

The functional annotation of the identified proteins obtained from STRAP database showed that these proteins are associated with binding property and regulatory function. In addition, these extracellular proteins would play an important role during ovulation. It is to be noted that proteins having binding property are widely present along with volatiles in body fluids and facilitate chemical communication during the estrus period [30,31]. A more recent report showed that the binding proteins are abundant during estrus compared to the other phases in estrous cycling mammals [32]. It clearly indicates that there is some specific role for the binding proteins during ovulation. The occurrence of large number of binding proteins during ovulation phase, assigning to molecular function, is an aspect of defence response and immunological process. The binding proteins may have a role in increasing the stability of other proteins [32].

Several salivary biomarkers such as Lactoferrin, Beta-2-microglobulin and Cystatin for Sjögren's syndrome, C-erbB-2, and Epidermal growth factor (EGF) for breast cancer, and Lactoferrin for periodontitis and type 2 diabetes mellitus have been listed using MS-based proteomic techniques [33, 34, 35]. The 2D gel electrophoresis (2-DE) is capable of providing for better biomarker separation (based on both charge and mass) and, therefore, expounds a higher number of biomarkers. In most of the studies, 2DE is used as the first step for protein separation, followed by tandem MS (MS/MS). The whole saliva separated by isoelectric focusing showed most distinctive proteins at different pls [36]. The outcome of the present study strongly agrees with the previous reports for the IEF separation between the pl 4-7. Recently, the 2DE analysis in periodontitis patients evidenced 15 altered spots out of 128[37]. Likewise, the present study revealed that 16 spots out of 62 were altered during the ovulation phase of menstrual cycle. 
Since the composition of salivary proteins is influenced by physiological and environmental factors, they have the potential to access and monitor the diseases [38, 24]. Indeed, the differences in protein expression have been well documented in pathological conditions such as cystic fibrosis, dental caries, and periodontitis $[39,40]$. So far, only limited proteomics studies have been carried out on human saliva with reference to variations in the different phases of menstrual cycle. On the other hand, proteomic analyses of saliva in ruminants are well established concerning estrous cycle. Electrophoretic separation revealed many distinct protein bands in sheep and goat parotid secretion [41, 42]. A comparative salivary proteomic study was undertaken between goats and sheep [28], and goats and cattle [43]. Likewise, salivary proteomics is a promising tool for the discovery of biomarkers for various diseases. Currently, researchers are interested in developing biochemical-based and/or protein-based marker from saliva for the detection of ovulation time in the human.

In order to make an in-depth salivary proteome analysis the following steps were followed: i) avoid protein loss and get enough protein concentration, ii) a good protein separation to avoid complexity of proteins and to remove abundant proteins, and iii) high mass accuracy peptides sequencing with resolution in scanning[44]. As reported previously, the total concentration of salivary proteins is low, and does not exceed approximately $2.5 \mathrm{mg} / \mathrm{mL}$ [45]. Generally, the concentration of proteins can be assessed by several techniques such as dialysis, lyophilization, reverse-phase separation, ultra-filtration, and enrichment by affinity columns or beads; the precipitation with TCA acetone or ammonium sulphate is also advisable $[46,47,48]$. The salivary proteins were efficiently extracted using TCA-acetone method followed by the method of Gehrke[17].Our previous study showed the $14.5 \mathrm{kDa}$ protein specifically expounded to be the dominant protein in saliva [16]. Similarly, the present study also confirms that the proteins in low molecular weight range are highly expressed in ovulation phase compared to other phases.

Recent proteomic platforms have showed about 3000 differentially expressed proteins and peptides in human saliva, many of which are of microbial origin [49]. Similarly, in the present study most of the proteins present in saliva are antimicrobial and defensive proteins. The proteins around $14.5 \mathrm{kDa}$, such as Cystatin-S, Prolactin-inducible protein, Cystatin-A,Cystatin-SN, BPI fold-containing family A member 2, Alpha-tubulin N-acetyltransferase 1, Carbonic anhydrase-6, Protein LEG1 homolog, Hemoglobin subunit beta, Pancreatic alpha-amylase are express at high levels during ovulation phase. Among these proteins, $14.5 \mathrm{kDa}$ Cystatin-S proteins were highly expressed as five isoforms falling in different pl ranges during ovulation phase. Further, the expression of Cystatin-S affirms the previous studies [16]. Likewise, CystatinA and cystatin isoforms were reported in gingival crevicular fluid in periodontal patients and chicken egg white during embryogenesis, respectively $[50,51]$. It is suggested that salivary glands respond to inflammation stimuli to secrete more Cystatin-C into saliva [50] and it has been considered as a biomarker candidate of renal function [52]. Alterations of serum Cystatin $\mathrm{C}$ was considered as early marker for hyperthyroidism, cancer, renal function in diabetic patients, and cardiovascular diseases [5356]. Cystatin $S$ is a promising tumor biomarker for early cancer diagnosis and treatment evaluation [57]. In many body fluids, Carbonic anhydrase (CA) appears to regulate acid-base balance [58], and possible expression of isoenzymes is found in human and animal reproductive organs [59]. Remarkably, CA is 
present during all phases of the estrous cycle of animals including cattle, camel and goat [28]. Additionally, the salivary proteins and microbiota serve as biomarkers to assess the early childhood caries risks [60]. In the present study, the variations in protein expression indicate that physiological changes influence the protein secretion in saliva. Hence, the specific expression of Cystatin-S in saliva during the ovulation phase would lead to bring up an important biomarker for ovulation detection in human.

\section{Conclusion}

The protein expression pattern in human saliva was characterized during different phases of menstrual cycle. The total salivary proteome profile is listed, and as many as 530 proteins appeared during ovulation phase as compared to 251 proteins of the post-ovulation phase. Functional annotation of the identified salivary proteins revealed them as extracellular proteins associated with regulatory function. The unique and differentially expressed protein spots during ovulation phase were identified and confirmed. Of these proteins Cystatin-S, Prolactin-inducible protein, Cystatin-A,Cystatin-SN, BPI foldcontaining family A member 2, Alpha-tubulin N-acetyltransferase 1, Carbonic anhydrase-6, Protein LEG1 homolog, Hemoglobin subunit beta, Pancreatic alpha-amylase are highly expressed during ovulation phase. Among the protein listed, Cystatin-S offers promise as a biomarker protein indicator of ovulation. Further study to characterize Cystatin-S to bring up a suitable indicator to detect ovulatory phase in human has been initiated.

\section{List Of Abbreviations}

HR-LC-MS/MS - -High Resolution Liquid Chromatograph Mass Spectrometer

MALDI TOF/TOF -Matrix Assisted Laser Desorption/Ionisation - Time of Flight

SDS-PAGE $\quad$-Sodium Dodecyl Sulfate-PolyAcrylamide Gel Electrophoresis

TCA -Trichloroacetic acid

DTT -Dithiothreitol

PRIDE - -PRoteomics IDEntifications

STARP -Software Tool for Rapid Annotation of Proteins

REViGO - Reduce and Visualize Gene Ontology

\section{Declarations}

\section{Ethics approval and consent to participate}


All the procedure adopted was approved by the Institutional Ethical Committee (DM/2014/101/38), Bharathidasan University, India. The saliva samples were collected from healthy female volunteers, with prior written consent.

\section{Consent to publish}

Not applicable

\section{Data availability}

The mass spectrometry proteomics data have been deposited to the ProteomeXchange Consortium (http://proteomecentral.proteomexchange.org) via the PRIDE partner repository with the dataset identifier PXD004511.

\section{Competing interests}

The authors declare that there is no conflict of interest regarding the publication of this paper.

\section{Funding}

No funding was received for this study.

\section{Acknowledgments}

G.S. (lead author) thanks the Indian Council of Medical Research (ICMR-New Delhi, India; No. 45/5/2014BIO/BMS) for the Senior Research Fellowship. G.A. thanks the University Grants Commission, New Delhi, for the award of UGC-BSR Faculty Fellow. Manali Jadhav and Pradnya Nikam thank SAIF, IIT-Bombay, Powai, Mumbai, for help in the LC-MS/MS analysis. The authors thank PRIDE Team for processing the data in the MS, which have been deposited with the ProteomeXchange Consortium.

\section{Authors' contributions}

GS (lead author) and GA involved in conceiving the idea; GS (lead author), SM,DR and GA designed the study; GS (lead author), DR, SM, GS, APA performed experimental and statiscal analysis; GS, APA, PP, BG, MAA and GA contributed to interpretation of data, and provided critical revision; GS (lead author), GA, MAA, SM, DR, BG, PP involved in writing manuscript and managing the overall progress of the study. The final manuscript was read and approved by all authors.

\section{References}

1. Humphrey SP, Williamson RT.A review of saliva: Normal composition, flow, and function. J Prosthet Dent.2001;85:162-9.

2. Dodds MWJ, Johnson DA,Yeh CK. Health benefits of saliva: A review. J Dent.2005;33:223-33. 
3. Lee YH, Wong DT. Saliva: An emerging biofluid for early detection of diseases. Am J Dent.2009;22:241-8.

4. Mass E, Gadoth N, Harell D, Wolff A. Can salivary composition and high flow rate explain the low caries rate in children with familial dysautonomia? Pediatr Dent. 2002;24:581-6.

5. Azevedo LF, et al. Analysis of the association between lactotransferrin (LTF) gene polymorphism and dental caries. J Appl Oral Sci. 2010;18:166-70.

6. Prout RE, Hopps RM. A relationship between human oral bacteria and the menstrual cycle. $J$ Periodontol.1970;41:98-101.

7. Pfaffe T, Cooper-White J, Beyerlein P, Kostner K, Punyadeera C. Diagnostic potential of saliva: current state and future applications. Clin Chem. 2011;57:675-87.

8. Martinez AR. Prediction and detection of the fertile phase of the menstrual cycle: an overview. Adv Contracept. 1997;13:131-8.

9. Baird DT. Prediction of ovulation, biophysical, physiological and biochemical coordinates. In: Jeffcoate SL, editor. Ovulation Methods for its Prediction and Detection. Chichester: John Wiley \& Sons, USA; 1983. p.1-17.

10. Albertson BD, Zinaman MJ. The prediction of ovulation and monitoring of the fertile period. Adv Contracept.1987;3:263-90.

11. Goswami B, Rajappa M, Sharmaand M, Sharma A. Inflammation: its role and interplay in the development of cancer, with special focus on gynecological malignancies. Int J Gynecol Cancer.2008;18:591-9.

12. Jabbour HN, Sales KJ, Catalano RD, Norman JE. Inflammatory pathways in female reproductive health and disease. Reproduction. 2009;138:903-19.

13. Saibaba G, Archunan G. Does salivary protein(s) act an ovulation indicator for women? A hypothesis. Med Hypotheses.2015;84:104-6.

14. Westermeier R. Electrophoresis in Practice, 3rd ed.WILEY-VCH; Weinheim, 2001.

15. Schwartz SS, Zhu WX, Sreebnyl LM. Sodium dodecyl sulphate-polyacrylamide gel electrophoresis of human whole saliva. Arch Oral Biol.1995;40:949-58.

16. Saibaba G, et al. Proteomic analysis of human saliva: An approach to find the marker protein for ovulation. Reprod Biol.2016;16:287-94.

17. Gehrke CW. Total protein extraction for IEF and 2-D SDS-PAGE. 2006. http://proteomics.missouri.edu/protocols.php. Accessed 23 Nov 2016.

18. Bradford MM. A rapid and sensitive method for the quantitation of microgram quantities of protein utilizing the principle of protein-dye binding. Anal Biochem.1926;72:248-54.

19. Laemmli UK. Cleavage of structural proteins during the assembly of the head of bacteriophage T4. Nature. 1970;227:680-5.

20. Dyballa N, Metzger S. Fast and sensitive colloidal coomassie G-250 staining for proteins in polyacrylamide gels. J Vis Exp. 2009;30:1431. 
21. Vizcaíno JA, et al. ProteomeXchange provides globally coordinated proteomics data submission and dissemination. Nature Biotechnol.2014;30:223-6.

22. Bhatia VN, Perlman DH, Costello CE, McComb ME. Software tool for researching annotations of proteins: Open-source protein annotation software with data visualization. AnalChem. 2009;81:981923.

23. Alagendran $S$, et al. Characterization of salivary protein during ovulatory phase of menstrual cycle through MALDI-TOF/MS. Ind J Dent Res. 2013;24:157-63.

24. Hofman LF. Human saliva as a diagnostic specimen. J Nutr.2001;131:1621-5.

25. Huang CM. Comparative proteomic analysis of human whole saliva. Arch Oral Biol.2004;49:951-62.

26. Millea KM, Krull IS, Chakraborty AB, Gebler JC,Berger SJ. Comparative profiling of human saliva by intact protein LC/ESI-TOF mass spectrometry. Biochim Biophys Acta. 2007;1774:897-906.

27. Helmerhorst EJ, Oppenheim FG. Saliva: a dynamic proteome. J Dent Res.2007;86:680-93.

28. Lamy E, et al. Sheep and goat saliva proteome analysis: a useful tool for ingestivebehavior research? Physiol Behav. 2009;98:393-401.

29. Castagnola M, et al. Salivary biomarkers and proteomics:future diagnostic and clinical utilities. Acta Otorhinolaryngol Ital.2017;37:94-101.

30. Vanmuylder N, Evrard L, Daeleman P, Van Reckand J, Dourov N. Expression of heat shock proteins in salivary gland tumors. Immunohistochemical study of HSP27, HSP70, HSP90, and HSP110: apropos of 50 cases. Ann Pathol.2000;20:190-5.

31. Achiraman S, Archunan G. Urinary proteins and pheromonal communication in mammals. Ind J ExpBiol.2002;40:1077-8.

32. Muthukumar S, et al. Exploration of salivary proteins in buffalo: an approach to find marker proteins for estrus. FASEB J. 2014;28:4700-9.

33. Caseiro A, et al. Salivary proteome and peptidome profiling in type 1 diabetes mellitus using a quantitative approach. J Proteome Res. 2013;12:1700-9.

34. Streckfus CF Dubinsky WP. Proteomic analysis of saliva for cancer diagnosis. Expert Rev Proteomics. 2007;4:329-32.

35. Al-Tarawneh SK, Border MB, Dibble CF, Bencharit S. Defining salivary biomarkers using mass spectrometry-based proteomics: A systematic review. OMICS. 2011;15:353-61.

36. Rudney JD, Staikov RK, Johnson JD. Potential biomarkers of human salivary function: a modified proteomic approach. Arch Oral Biol. 2009;54:91-100.

37. Haigh BJ, et al. Alterations in the salivary proteome associated with periodontitis. J Clin Periodontol. 2010;37:241-7.

38. Tsai H, Bobek LA. Human salivary histatins: promising anti-fungal therapeutic agents. Crit Rev Oral Biol Med. 1998;9:480-97.

39. Anil S, Remani P, Beena VT, Nair RG, Vijayakumar T. Immunoglobulins in the saliva of diabetic patients with periodontitis. Ann Dent.1995;54:30-3. 
40. Tang X, Pan Y, Wang Z. Sodium dodecyle sulphate polyacrylamide gel electrophoresis of whole salivary proteins from patients with adult periodontitis. Hua Xi Kou Qiang Yi XueZaZhi.2003;21:98100.

41. Patterson J, Brightling P, Titchen DA. Beta-Adrenergic effects on composition of parotid salivary secretion of sheep on feeding. Q J Exp Physiol. 1982;67:57-67.

42. McLaren RD, Mcintosh JT, Howe GW. The purification and characterization of bovine salivary proteins by electrophoretic procedures. Electrophoresis. 1987;8:318-24.

43. Mau M, Muller C,Langbein J, Rehfeldt C, Hildebrandt JP, Kaiser TM. Adhesion of bovine and goat salivary proteins to dental enamel and silicate. Arch. Tierz. 2006;49:439-46.

44. Adachi J, Kumar C, Zhang Y, Olsenand JV, Mann M. The human urinary proteome contains more than 1500 proteins, including a large proportion of membrane proteins. Genome Biol. 2006;7:80-96.

45. Saibaba G, Srinivasan M, Priya Aarthy A, Silambarasan V, Archunan G. Ultrastructural and physicochemical characterization of saliva during menstrual cycle in perspective of ovulation in human. Drug DiscovTher. 2017;11:91-97.

46. Sun $\mathrm{W}$, et al. Human urine proteome analysis by three separation approaches.

Proteomics.2005;5:4994-5001.

47. Tantipaiboonwong T, Sinchaikul S, Sriyam S, Phutrakul S, Chen ST. Different techniques for urinary protein analysis of normal and lung cancer patients. Proteomics. 2005;5:1140-9.

48. Wang L, et al. Concanavalin A-captured glycoproteins in healthy human urine. Mol Cell Proteomics. 2006;5:560-2.

49. Grassl N, et al. Ultra-deep and quantitative saliva proteome reveals dynamics of the oral microbiome. Genome Med. 2016;8:44.

50. Blankenvoorde MF, et al. Cystatin A in gingival crevicular fluid of periodontal patients. J Periodontal Res. 1997;32:583-8.

51. Golab K, Gburek J, Gawel A, Warwas M. Changes in chicken egg white cystatin concentration and isoforms during embryogenesis. Br Poult Sci. 2001;42:394-8.

52. Jiang R, Xu C, Zhou X, Wangand T, Yao G. Detection of cystatin C biomarker for clinical measurement of renal disease by developed ELISA diagnostic kits. J TransI Med. 2014;12:205.

53. Jayagopal V, Keevil BG, Atkin SL, Jennings PE, Kilpatrick ES. Paradoxical changes in cystatin C and serum creatinine in patients with hypo- and hyperthyroidism. Clin Chem. 2003;49:680-701.

54. Ohara G, et al. Serum levels of cystatin C in elderly lung cancer patients. Oncol Lett. 2012;3:303-6.

55. Vega A, et al. Evaluation of methods based on creatinine and cystatin $C$ to estimate glomerular filtration rate in chronic kidney disease. Int Urol Nephrol. 2014;46:1161-7.

56. Svensson-Färbom P, et al. Cystatin C identifies cardiovascular risk better than creatinine-based estimates of glomerular filtration in middle-aged individuals without a history of cardiovascular disease. J Intern Med. 2014;275:506-21. 
57. Xiaojin Z, et al. Clinical significance of Cystatin S in cancer diagnosis and treatment assessment. J Clin Oncol. 2014;32:e22226.

58. Mühlhauser J, et al. Immunohistochemistry of carbonic anhydrase in human placenta and fetal membranes. Histochemistry. 1994;101:91-8.

59. Ekstedt E, RidderstrÂle R. Histochemical localization of carbonic anhydrase in the testis and epididymis of the rabbit. ActaAnat. 1992;143:258-64.

60. Hemadi AS, Huang R, Zhou Y, Zou J. Salivary proteins and microbiota as biomarkers for early childhood caries risk assessment. Int J Oral Sci. 2017;9:e1.

\section{Tables}

Table 1. List of functionally important salivary proteins identified during ovulatory phase of menstrual cycle. 


\begin{tabular}{|c|c|c|c|c|c|}
\hline $\begin{array}{l}\text { Swiss- } \\
\text { Prot }\end{array}$ & Name & Function $^{b}$ & $\mathrm{pl}^{\mathrm{c}}$ & $M W^{d}$ & Lengthe \\
\hline \multicolumn{6}{|l|}{ acc. no. ${ }^{a}$} \\
\hline P01036 & Cystatin-S & Strong inhibitor & 4.83 & 14.18 & 141 \\
\hline Q9H2U9 & $\begin{array}{l}\text { Disintegrin and } \\
\text { metalloproteinase } \\
\text { domain-containing } \\
\text { protein } 7\end{array}$ & Role in Reproduction & 5.92 & 65.09 & 754 \\
\hline Q9UHD2 & TANK-binding kinase 1 & $\begin{array}{l}\text { Regulating inflammatory } \\
\text { responses }\end{array}$ & 6.32 & 83.64 & 729 \\
\hline Q9UIA9 & Exportin 7 & Export of proteins & 5.91 & 123.9 & 1087 \\
\hline P29122 & $\begin{array}{l}\text { Proprotein convertase } \\
\text { subtilisin/kexin type } 6\end{array}$ & Endoprotease activity & 7.96 & 106.4 & 969 \\
\hline Q14031 & $\begin{array}{l}\text { Collagen alpha-6(IV) } \\
\text { chain }\end{array}$ & Major structural component & 9.31 & 163.8 & 1691 \\
\hline Q5FYB1 & Arylsulfatase I & $\begin{array}{l}\text { Displays arylsulfatase activity } \\
\text { at neutral pH }\end{array}$ & 8.82 & 64.03 & 569 \\
\hline P02768 & Serum albumin & $\begin{array}{l}\text { Binding capacity for water, } \\
\mathrm{Ca}(2+), \mathrm{Na}(+), \mathrm{K}(+) \text {, fatty acids, } \\
\text { hormones, bilirubin and drugs }\end{array}$ & 5.92 & 69.36 & 609 \\
\hline Q5XXA6 & Anoctamin-1 & Chloride conductance & 8.76 & 114.07 & 986 \\
\hline Q9Y5E6 & Protocadherin beta-3 & $\begin{array}{l}\text { Potential calcium-dependent } \\
\text { cell- adhesion protein }\end{array}$ & 4.88 & 86.77 & 796 \\
\hline P28566 & $\begin{array}{l}\text { 5-hydroxytryptamine } \\
\text { receptor }\end{array}$ & G-protein coupled receptor & 9.09 & 41.68 & 365 \\
\hline Q496J9 & $\begin{array}{l}\text { Synaptic vesicle } \\
\text { glycoprotein } 2 \mathrm{C}\end{array}$ & $\begin{array}{l}\text { Positively regulates vesicle } \\
\text { fusion }\end{array}$ & 4.92 & 82.34 & 727 \\
\hline Q8WXI7 & Mucin-16 & Protective, lubricating barrier & - & - & 22152 \\
\hline Q969D9 & $\begin{array}{l}\text { Thymic stromal } \\
\text { lymphopoietin }\end{array}$ & $\begin{array}{l}\text { Antimicrobial peptide in the } \\
\text { oral cavity }\end{array}$ & 9.75 & 18.14 & 159 \\
\hline Q8TE04 & Pantothenate kinase 1 & $\begin{array}{l}\text { Role in the physiological } \\
\text { regulation }\end{array}$ & 7.51 & 64.33 & 598 \\
\hline P50453 & Serpin B9 & Protease inhibitor & 5.61 & 42.40 & 376 \\
\hline Q8TD43 & $\begin{array}{l}\text { Transient receptor } \\
\text { (TRPM4) }\end{array}$ & $\begin{array}{l}\text { Mediates transport of } \\
\text { monovalent cations }\end{array}$ & 8.49 & 134.3 & 1214 \\
\hline Q3YEC7 & Rab-like protein 6 & $\begin{array}{l}\text { May enhance cellular } \\
\text { proliferation }\end{array}$ & 5.11 & 79.54 & 729 \\
\hline Q13733 & $\begin{array}{l}\text { Sodium/potassium- } \\
\text { transporting ATPase subunit } \\
\text { alpha-4 }\end{array}$ & $\begin{array}{l}\text { Hydrolysis of ATP coupled } \\
\text { with the exchange of } \\
\text { sodium and potassium } \\
\text { ions }\end{array}$ & 6.23 & 114.1 & 1029 \\
\hline
\end{tabular}

acc.
Q910
Q9UH
Q9UIA
P291
Q14031
Q5FY
P027
Q5XX
Q9Y5
P285
Q496
Q8WXI7
Q969
Q8TE
P504
Q8TD
Q3YE
Q13733

Transcriptional regulation $\quad 9.09 \quad 55.19 \quad 486$

Q8N587 Z Zinc finger protein 561 responses 


\begin{tabular}{|c|c|c|c|c|c|}
\hline 075177 & $\begin{array}{l}\text { Calcium-responsive } \\
\text { transactivator }\end{array}$ & $\begin{array}{l}\text { calcium-dependent } \\
\text { dendritic growth }\end{array}$ & 5.96 & 42.99 & 396 \\
\hline \multirow[t]{2}{*}{ Q9H6R6 } & $\begin{array}{l}\text { Palmitoyltransferase } \\
\text { ZDHHC6 }\end{array}$ & $\begin{array}{l}\text { Palmitoylates calnexin (CALX), } \\
\text { which is required for its } \\
\text { association with the ribosome } \\
\text { translocon complex and } \\
\text { efficient }\end{array}$ & 8.81 & 47.66 & 413 \\
\hline & & $\begin{array}{l}\text { folding of glycosylated } \\
\text { proteins. }\end{array}$ & & & \\
\hline Q05JX5 & Apolipoprotein B & lon binding & 8.41 & 46.48 & 384 \\
\hline P16112 & Aggrecan core protein & $\begin{array}{l}\text { Resist compression in } \\
\text { cartilage }\end{array}$ & 4.10 & 250.1 & 2399 \\
\hline Q5EK51 & Lactotransferrin & Anti microbial response & 8.56 & 78.32 & 711 \\
\hline \multirow[t]{2}{*}{ Q8N4F0 } & Bactericidal/permeability- & Lipid binding & 8.82 & 49.17 & 458 \\
\hline & increasing protein-like 1 & & & & \\
\hline 000154 & Acyl-CoA thioesterase 7 & Hydrolysis of acyl-CoAs & 8.85 & 41.79 & 380 \\
\hline P12273 & Prolactin-induced protein & Protein binding & 8.26 & 16.57 & 146 \\
\hline P23284 & Peptidylprolyl isomerase B & $\begin{array}{l}\text { Accelerate the folding of } \\
\text { proteins }\end{array}$ & 9.42 & 23.74 & 216 \\
\hline P23280 & Carbonic anhydrase 6 & Unknown & 6.51 & 35.36 & 308 \\
\hline P49895 & Deiodinase & $\begin{array}{l}\text { Hormone biosynthetic } \\
\text { process }\end{array}$ & 8.90 & 28.92 & 249 \\
\hline Q59FP8 & Neogenin & Unknown & 6.56 & 123.9 & 1130 \\
\hline
\end{tabular}

${ }^{a, e}$ Proteins having at least one identified peptide in ovulation phase saliva are listed with their Swiss-Prot/TrEmbl accession numbers and length.

${ }^{b}$ Functions were retrieved using the STRAP online database bioinformatics resource.

${ }^{c, d}$ Theoretical pls and monoisotopic molecular weights were calculated using the Swiss-Prot website.

Table 2. Mass values of cystatin-S. Observed and expected masses $(M+H)$ of cystatin-S protein and tryptic digested peptide sequence map by MALDI-TOF/MS, which was retrieved from Mascot database. The matched peptides are bolded in black. 


\begin{tabular}{ccccl}
\hline $\begin{array}{c}\text { Start- } \\
\text { End }\end{array}$ & $\begin{array}{c}\text { Observed } \\
\text { mass }\end{array}$ & $\begin{array}{c}\text { Expected } \\
\text { mass }\end{array}$ & $\begin{array}{c}\text { Calculated } \\
\text { mass }\end{array}$ & \multicolumn{1}{c}{ Peptide sequence } \\
\hline $1-24$ & & & 2488.3579 & MARPLCTLLLLMATLAGALASSSK \\
$25-28$ & & & 546.2398 & EENR \\
$29-46$ & 2074.6160 & 2073.6087 & 2073.0167 & IIPGGIYDADLNDEWVQR \\
$47-57$ & 1293.0520 & 1292.0447 & 1291.6561 & ALHFAISEYNK \\
$58-65$ & 1046.8020 & 1045.7947 & 1045.4352 & ATEDEYYR \\
$66-72$ & 881.8430 & 880.8357 & 880.5607 & RPLQVLR \\
$73-74$ & & & 245.1488 & AR \\
$75-91$ & 1964.5230 & 1963.5157 & 1962.9112 & EQTFGGVNYFFDVEVGR \\
$92-96$ & & & 621.3156 & TICTK \\
$97-114$ & 2142.5570 & 2141.5497 & 2140.9848 & SQPNLDTCAFHEQPELQK \\
$115-$ & & & 146.1055 & K \\
115 & & & & \\
$116-$ & 1971.2200 & 1970.2127 & 1969.8880 & QLCSFEIYEVPWEDR \\
130 & & & 805.4116 & MSLVNSR \\
$131-$ & & & & \\
137 & & & 821.4065 & MSLVNSR + Oxidation (M) \\
$131-$ & 823.3630 & 822.3557 & & \\
137 & & & 506.1795 & CQEA \\
$138-$ & & & & \\
141 & & & & \\
\hline
\end{tabular}

Table 3. List of highly and specifically expressed proteins in saliva during ovulation phase.

\begin{tabular}{lllll}
\hline Spot no & Protein Name & Accession code $^{\mathbf{a}}$ & $\mathbf{p I}^{\mathbf{b}}$ & $\mathbf{M W}(\mathbf{k D a})^{\mathbf{c}}$ \\
\hline 1 & Cystatin-S & P01036 & 4.95 & 16.21 \\
2 & Prolactin-inducible protein & P12273 & 8.26 & 16.57 \\
3 & Cystatin-S & P01036 & 4.95 & 16.21 \\
4 & Cystatin-S & P01036 & 4.95 & 16.21 \\
5 & Cystatin-A & P01040 & 5.38 & 11.00 \\
6 & Cystatin-A & P01040 & 5.38 & 11.00 \\
7 & Cystatin-S & P01036 & 4.95 & 16.21 \\
8 & Cystatin-SN & P01037 & 6.73 & 16.38 \\
9 & BPI fold-containing family A member 2 & Q96DR5 & 5.35 & 27.01 \\
10 & Cystatin-S & P01036 & 4.95 & 16.21 \\
11 & Alpha-tubulin N-acetyltransferase 1 & Q5SQI0 & 5.78 & 37.92 \\
12 & Carbonic anhydrase 6 & P23280 & 6.51 & 35.36 \\
13 & Protein LEG1 homolog & Q6P5S2 & 5.78 & 37.90 \\
14 & Hemoglobin subunit beta & P18984 & 7.24 & 16.06 \\
15 & Carbonic anhydrase 6 & P23280 & 6.51 & 35.36 \\
16 & Pancreatic alpha-amylase & P00690 & 6.52 & 50.07 \\
\hline
\end{tabular}

a Proteins having identified peptides in ovulation period saliva are listed with their SwissProt/Uniprot accession numbers.

b,c Theoretical pIs and monoisotopic molecular weights were calculated using the SwissProt website (http://web.expasy.org/compute_pi/)

\section{Additional File Legends}


Figure S1. The schematic representation of work flow of the present study.

Figure S2. Confirmation of ovulation. A) An ultrasound image of the dominant follicle size about 20 mm of Left Ovary (LO). B) Salivary Fern Pattern.

Figure S3. Functional annotation of the salivary proteins. A) Biological process, B) Cellular component, C) Molecular function. Functional annotation was carried out by using STRAP 1.5 online database and found most of the identified proteins to be associated with binding property and regulatory function.

Figure S4. Molecular function analysis. Most of the proteins thus identified to possess binding property

File.S1. The protein dataset of ovulation.

File.S2. The protein dataset of post-ovulation.

\section{Figures}

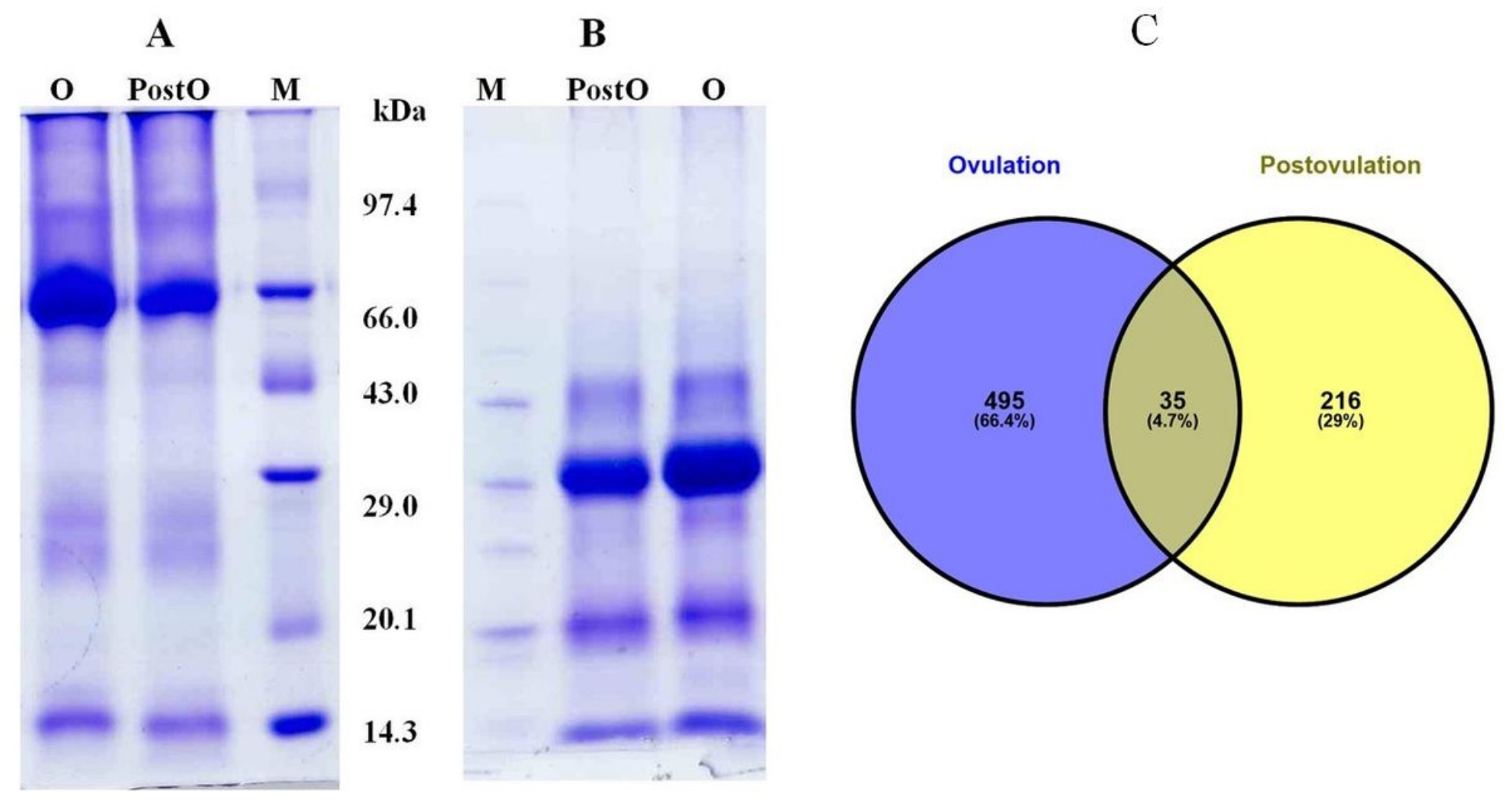

\section{Figure 1}

Figure 1. A) Salivary protein profile in $12 \%$ SDS-PAGE. O- Ovulation phase, PostO- Post-ovulation phase, M-Protein marker. B) Salivary protein profile in gradient gel (5-15\%). O-Ovulation phase, PostO- Postovulation phase, M- Protein marker. C) Venn diagram for overall identified salivary proteins. In ovulation phase 495 proteins showed up whereas 216 proteins were observed during post-ovulation phase. 
A)

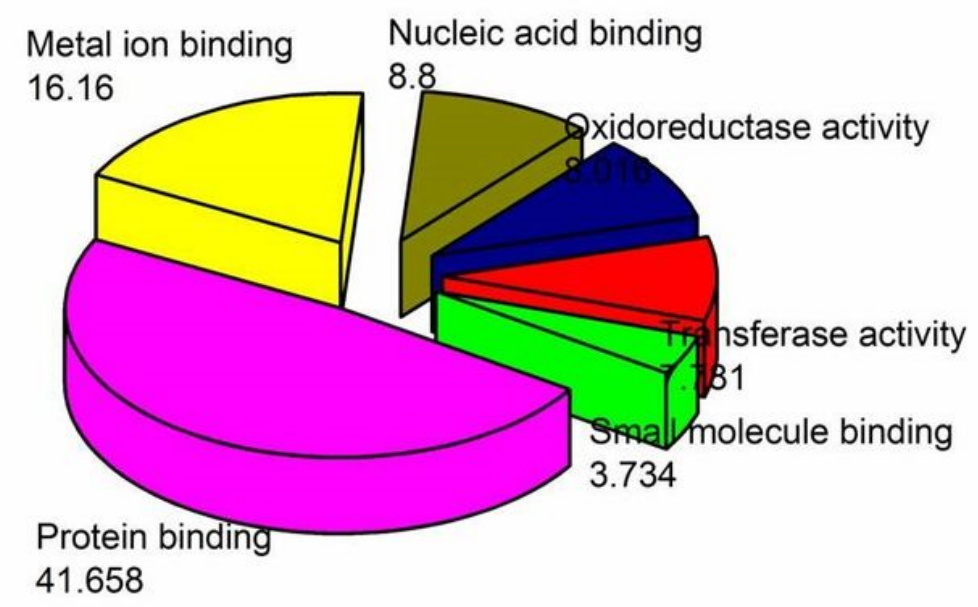

B)

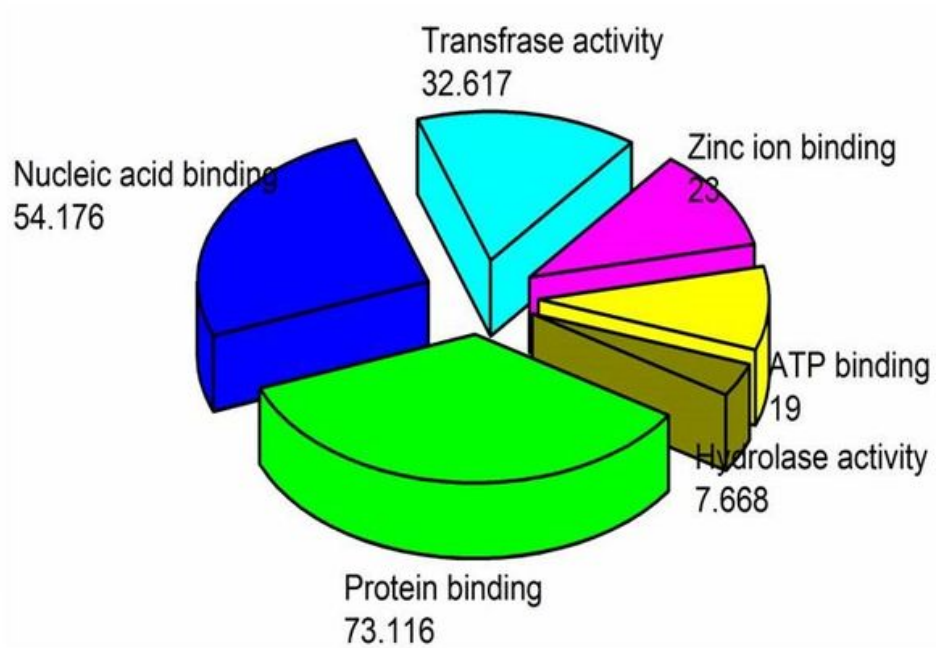

\section{Figure 2}

Figure 2. The score distribution according to molecular functional ontology. A) Ovulation phase, B) Postovulation phase. Protein domain entries used to depict the percentage of proteins through Interproscan analysis in BLAST2GO.

A

Ovulation

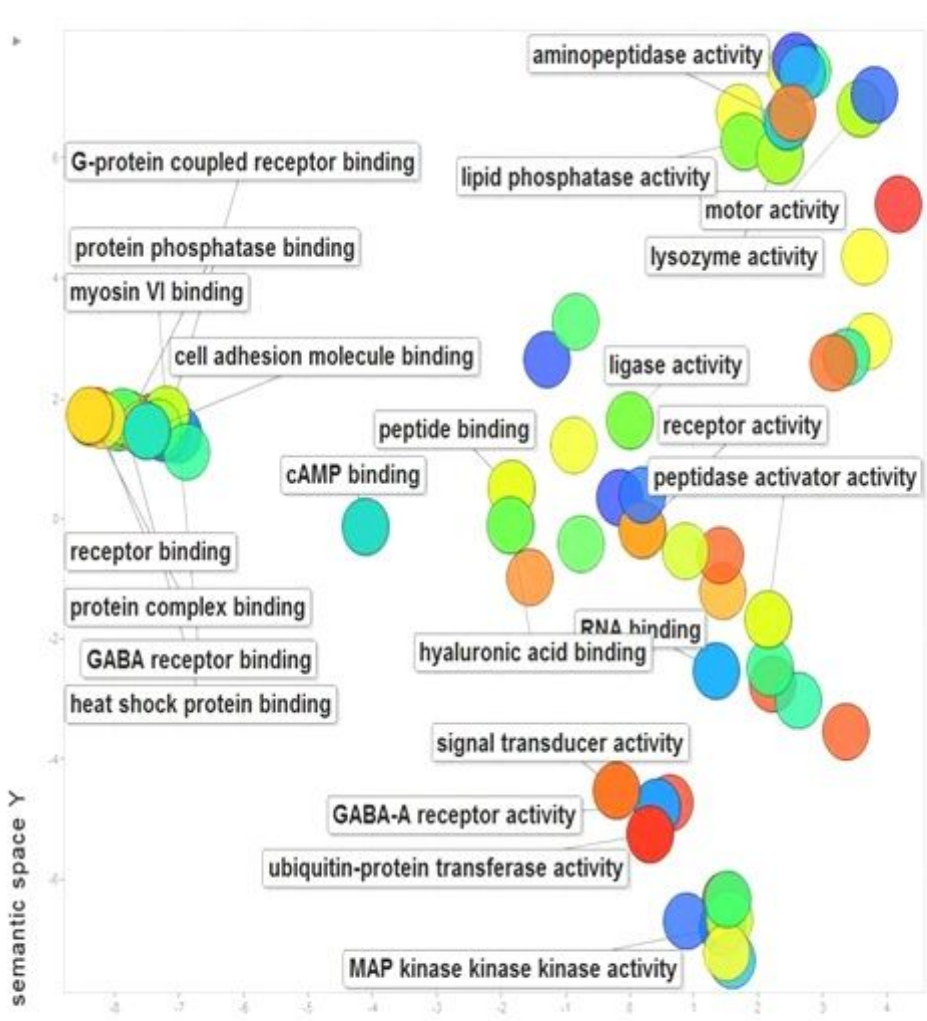

semantic space $X$
B

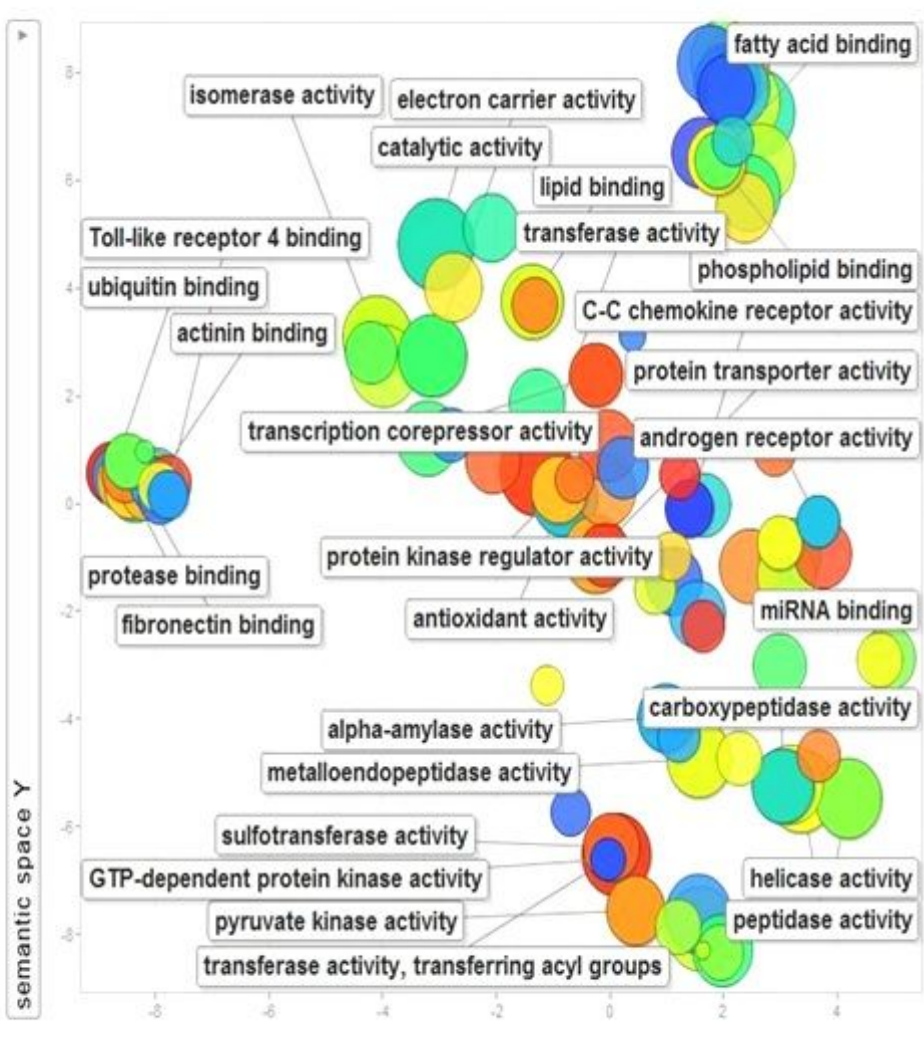

semantic space $X$

\section{Figure 3}


Scatter plot of molecular functions of proteins. The plots show the clusters of protein and activity in A) ovulation and B) post-ovulation phases. The ovulation plot has the higher number of binding and lesser activity protein compared to post-ovulation stage.

A

${ }_{\mathrm{Mr}}$

97.4

66.0

43.0

29.0

20.1

14.3
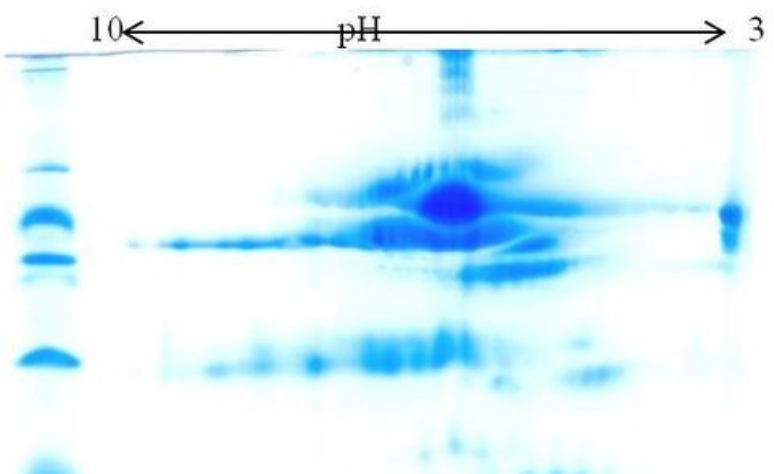

-

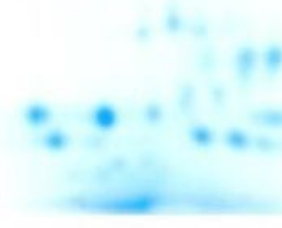

B 97 66.0 43.0

29.0

20.1

14.3

II

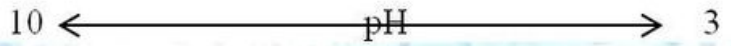

7.4

6.0

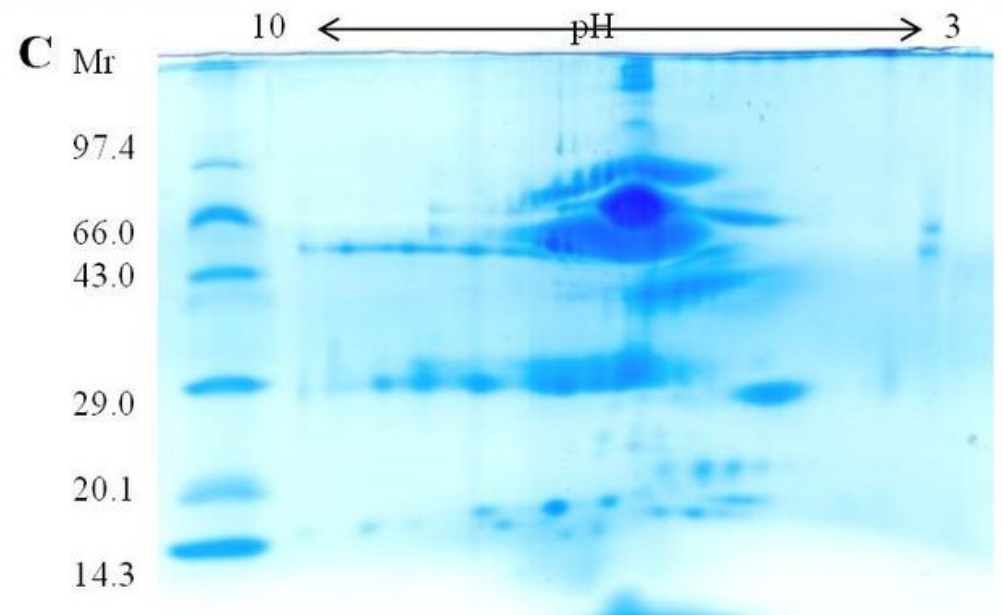

\section{Figure 4}

Figure 4. The 2D gel electropherogram of salivary proteins round the menstrual cycle. A) Pre-ovulation phase, B) Ovulation phase, C) Post-ovulation phase. The $11 \mathrm{~cm}$ IPG strips were used with 3-10 pH range and gel run with the $12 \%$ SDS-PAGE. 


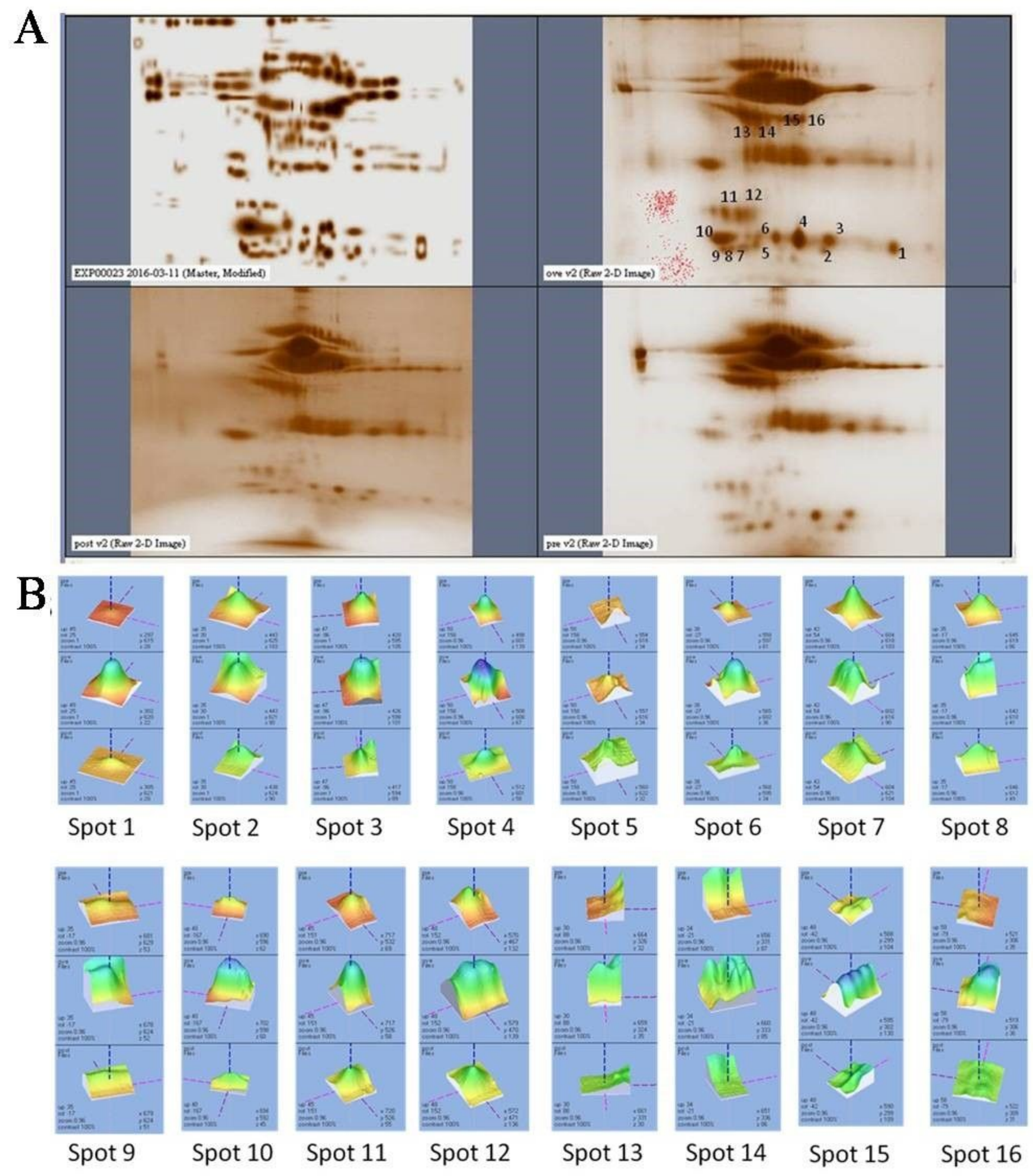

Figure 5

Figure 5. Multi-channel image of 2D gel. A) The unique protein spots during ovulation phase. B) The expression level of spot 1 in pre-ovulation, ovulation and post-ovulation phases from the top respectively, by Melanie 3D viewer. 


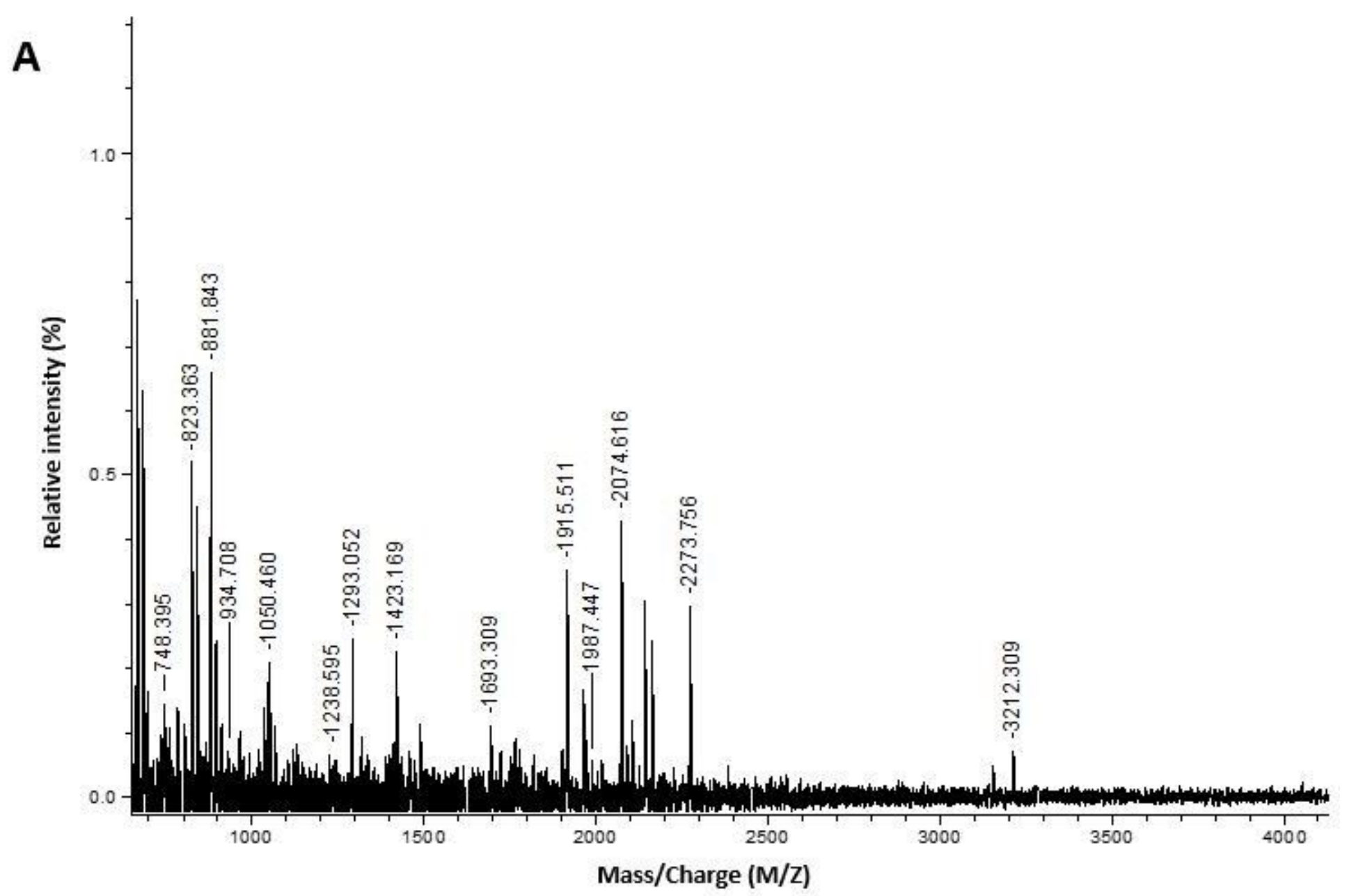

B

$\begin{array}{rlllll}1 & \text { MARPLCTLLL } & \text { LMATLAGALA } & \text { SSSKEENRII } & \text { PGGIYDADLN } & \text { DEWVQRALHF } \\ 51 & \text { AISEYNKATE } & \text { DEYYRRPLQV } & \text { LRAREQTFGG } & \text { VNYFFDVEVG } & \text { RTICTKSQPN } \\ 101 & \text { LDTCAFHEQP } & \text { ELQKKQLCSF } & \text { EIYEVPWEDR } & \text { MSLVNSRCQE } & \text { A }\end{array}$

Figure 6

Figure 6. MALDI-mass spectrum and Sequence coverage of cystatin-S. (a) 2D Protein spot 1 was undergone for in-gel tryptic digestion and the spectra was collected form MALDI-MS. Number in the mass spectrum gives precise $\mathrm{m} / \mathrm{z}(\mathrm{M}+\mathrm{H})$ values for detected peptide ion signals. (b) Single letter coded protein sequence was obtained from mascot search. The matched $71 \%$ sequence coverage was highlighted in red colour.

\section{Supplementary Files}

This is a list of supplementary files associated with this preprint. Click to download.

- Supplementaryfile.S1.xlsx

- FigS4.jpg 
- S3.tif

- SupplementaryFigureS2.jpg

- S1.tif

- Supplementaryfile.S2.xlsx 